\title{
The Fate of Beta-Lactam Resistance Determinats within the Wastewater Treatment Plant in Żywiec and in Final Effluent Receiving Żywieckie Lake
}

\author{
Kinga Bondarczuk, Zofia Piotrowska-Seget \\ University of Silesia, Department of Microbiology \\ 28 Jagiellońska Street, 40-032 Katowice, Poland \\ kinga.bondarczuk@us.edu.pl, zofia.piotrowska-seget@us.edu.pl
}

\section{Extended Abstract}

Antibiotic resistance has been becoming a global problem threatening modern medicine. Thorough studies on this phenomenon have uncovered the crucial role of the environment in the development and the dissemination of this trait among bacteria. Wastewater treatment plants have been recognised as hotspots for antibiotic-reistant bacteria and antibiotic resistance genes [1]. Moreover, it has been suggested that the specific conditions within wastewater treatment plants such as sublethal concentrations of antibiotics and high microbial density favour horizontal transfer of resistance genes [2]. However, little do we know about the fate of antibiotic resistance determinants and antibiotic-resistant bacteria in treated sewage receiving water bodies. The already available results range from small effect to a significant impact depending on screened genes/bacteria and different water ecosystems [3], [4]. Hence more studies are needed to clarify which genes are more persistent in given environments.

The aim of the study was to track the fate of $\beta$-lactam-resistant bacteria and $\beta$-lactam resistance plasmids within a wastewater treatment plant during the treatment process and in a final effluent receiving environment. For this purpose samples of raw sewage, activated sludge, final effluent, Żywieckie Lake water and sediment were collected. Water and sediment samples from the Soła River upstream the lake were also included to the analysis as control. The number of ampicillin-resistant and total culturable heterotrophic bacteria was determined using LB-agar or ampicillin-amended LBagar plates, respectively. Ampicillin resistance plasmids were isolated by exogenous method and subsequently transformed to $E$. coli cells for further analysis.

The study revealed that even though the treatment process notably decreases the number of resistant bacteria (a 100 fold decrease when compared to raw sewage), they are still released in significant amounts (103CFU/ml of treated sewage). On the other hand, the results obtained from the Sola River uncovered the existence of considerable resistome in this environment suggesting that it may be impacted by other sources of antibiotic-resistant bacteria such as illegal untreated sewage dumping from private households. An ampicillin resistance plasmid library in E. coli cells was set and the replicons were characterised.

The research is supported by National Science Centre grant 2014/13/N/NZ9/03915. KB had been receiving a scholarship provided by the "DoktoRIS - Scholarship programme for innovative Silesia", which was co-financed by the European Union under the European Social Fund covered by Human Capital Programme.

\section{References}

[1] L. Rizzo, C. Manaia, C. Merlin, T. Schwartz, C. Dagot, M. C. Ploy, I. Michael, and D. Fatta-Kassinos, "Urban wastewater treatment plants as hotspots for antibiotic resistant bacteria and genes spread into the environment: A review," Sci. Total Environ., vol. 447, pp. 345-360, 2013.

[2] T. Zhang, X.-X. Zhang, and L. Ye, "Plasmid metagenome reveals high levels of antibiotic resistance genes and mobile genetic elements in activated sludge," PLoS One, vol. 6, no. 10, p. e26041, 2011.

[3] L. Proia, D. von Schiller, A. Sànchez-Melsió, S. Sabater, C. M. Borrego, S. Rodríguez-Mozaz, and J. L. Balcázar, "Occurrence and persistence of antibiotic resistance genes in river biofilms after wastewater inputs in small rivers.," Environ. Pollut., vol. 210, pp. 121-128, 2015.

[4] T. M. LaPara, M. Madson, S. Borchardt, K. S. Lang, and T. J. Johnson, "Multiple discharges of treated municipal 
wastewater have a small effect on the quantities of numerous antibiotic resistance determinants in the upper Mississippi River," Environ. Sci. Technol., p. 150910082453007, 2015. 